\title{
Quarantine Redux: Bioterrorism, AIDS and the Curtailment of Individual Liberty in the Name of Public Health
}

Wendy E. Parmet

Follow this and additional works at: https://scholarlycommons.law.case.edu/healthmatrix

Part of the Health Law and Policy Commons

\section{Recommended Citation}

Wendy E. Parmet, Quarantine Redux: Bioterrorism, AIDS and the Curtailment of Individual Liberty in the Name of Public Health, 13 Health Matrix 85 (2013)

Available at: https://scholarlycommons.law.case.edu/healthmatrix/vol13/iss1/7 


\title{
QUARANTINE REDUX: \\ BIOTERRORISM, AIDS AND THE \\ CURTAILMENT OF INDIVIDUAL \\ LIBERTY IN THE NAME OF PUBLIC \\ HEALTH
}

\author{
Wendy E. Parmet ${ }^{\dagger \neq}$
}

Novel sources of death are especially frightening. In the early 1980 s, the emergence of the AIDS epidemic was the source not only of suffering and loss, but also of fear, hysteria, and irrationality. It was in that heated climate that public debate turned to the questions of when and whether government may infringe upon individual liberties in order to protect public health. ${ }^{1}$

Although AIDS is still with us, and indeed it causes more suffering each year, ${ }^{2}$ in the United States it is no longer the public health threat that induces the greatest fears. Bioterrorism may now claim that honor. And so it now provokes the old debate pitting individual liberties against the state.

The confluence of the terrorist attacks on the United States last September and the anthrax mail attacks in the subsequent weeks focused attention and fear on the use of pathogens as weapons of mass

${ }^{\dagger}$ Professor of Law, Northeastern University School of Law. Many thanks to Anthony Robbins, M.D. and Anthony Moulton, Ph.D., for their comments on an earlier version of the paper, to Daniel McCabe, Jennifer Hoenig, Jamie Quigley, Kevin Pechulis, David Roberts and Jason Smith for their wonderful help researching this paper, and to Jan McNew for her terrific secretarial assistance. All opinions and errors are my own.

$\$$ This paper was written in September 2002 and does not discuss developments in the field subsequent to that date.

${ }^{1}$ The literature from that time is extensive. For a few examples, see Ronald Bayer, Private Acts, Social Consequences: AIDS and the Politics of PUBLIC HEALTH (1989); see also Scott Burris, Fear Itself: AIDS, Herpes, and Public Health Decisions, 3 YALE L. \& PoL'Y REV. 479 (1985) (discussing the role of health law as related to individual rights against the public good).

${ }^{2}$ The Report on the Global HIV/AIDS Epidemic: The Barcelona Report, UNAIDS, XIV International Conference on AIDS (July 2002) (reporting the latest global HIV/AIDS statistics and putting forth new suggestions on how to better deal with the crisis), available at http://www.unaids.org/barcelona/presskit/report.html. 
destruction. In response, the Centers for Disease Control and Prevention ("CDC"), in collaboration with the National Governors Association, the National Conference on State Legislatures, the Association of State and Territorial Health Officials and the National Association of County and City Health Officials commissioned the center for Law and the Public's Health at Georgetown and Johns Hopkins Universities ("the Center") to develop a model act for states to consider enacting in preparation for bioterrorism. In November 2001, the Center released a draft version of the "Model State Emergency Health Powers Act" ("Model Act") which was revised in December. ${ }^{3}$ Many states are now considering legislation based upon the Model Act. ${ }^{4}$

Although the two versions of the Model Act differ significantly in many ways, both would grant governors the ability to declare a public health emergency which would then permit the imposition of isolation, quarantine, mandatory medical examinations, and other coercive measures. ${ }^{5}$ In effect, both versions of the Model Act grant states coercive powers in order to meet the threat of bioterrorism. At the same time, the Model Act's authors attempt to mediate the perceived clash between the use of the coercive powers and individual rights. The preamble states that

the Act recognizes that a state's ability to respond to a public health emergency must respect the dignity and rights of persons .... The Act thus provides that, in the event of the exercise of emergency powers, the civil rights, liberties, and needs of infected or exposed persons will be protected to the fullest extent possible consistent with the primary goal of controlling serious health threats. ${ }^{6}$

As Yogi Berra has been quoted as saying, "It's déjà vu all over again!" As in the early years of the HIV epidemic, public health appears to be in conflict with the rights of the individual. In the case of HIV, many have argued that "exceptional" policies prevailed and that

${ }^{3}$ The Model State Emergency Health Powers Act (Center for Law and the Public Health at Georgetown and John Hopkins Universities, Draft for Discussion 2001), at http://www.publichealthlaw.net/msehpa/msehpa2.pdf (Dec. 21, 2001) [hereinafter MODEL ACT].

${ }^{4}$ See The Model State Emergency Health Powers Act: State Legislative Activity (as of Oct. 1, 2002) (compiling all 50 states activity relating to the Model State Emergency Health Powers Act), available at http://www.pubichealthlaw.net/MSEHPA_Leg_Activity_050102.pdf.

${ }_{5}^{5}$ See text accompanying notes $27-54$, infra.

6 MODEL ACT, supra note 3, at Preamble. 
protection of the public health gave way to individual rights. ${ }^{7}$ This time around, with a new, perhaps even scarier threat, the outcome should be different, or so the proponents of the Model Act would proclaim. But have we learned the right lessons?

In this Article, I review a revised version of the Model Act in light of public health law's encounter with HIV. I begin in Part I by reviewing the Model Act and other legal responses that have been adopted or proposed with respect to bioterrorism. In Part II, I discuss the debates that emerged in the 1980s and early 1990s about individual rights in the wake of HIV. I suggest that although the government did not by and large adopt coercive policies with respect to HIV, a consensus developed, at least among policymakers and influential public health theorists, that HIV was treated exceptionally, and that the "normal" approach to public health threats is to invoke "traditional police powers" that allow for placing restraints upon individual liberty. ${ }^{8}$ In Part III, I question that consensus, arguing that "traditional police powers" are far more varied than is often appreciated. In particular, I discuss the important role that social and structural reforms, as well as education, have long played in the protection of public health. Restraint on individual liberty, I contend, has been a far less critical part of public health's legal palate than is commonly assumed. In Part IV, I turn to the role of law and legal procedures in mediating the rights of the individual and the interests of the state in the face of public health threats. Here I caution against excessive confidence in modern statutes and judicial review as arbiters of the tensions that exist between individuals and public health. Although courts played a vital role in protecting individual rights during the AIDS epidemic, I question whether they can or will do so during the next public health emergency. Finally in Part VI return to bioterrorism I also suggest that our legal preparations for bioterrorism should not rely too heavily on laws pertaining to individual restraints and rights. Such an approach may lull political leaders and others into thinking they have solved a problem when they have not. Rather than rely unduly on constraints upon individuals, we must look to other more complex and perhaps more expensive legal approaches that may help not only to

7 See Ronald Bayer, Public Health Policy and the AIDS Epidemic: An End to HIV Exceptionalism? 324 NEW. ENG. J. MED. 1500 (1991) (arguing that the public health response to AIDS has differed from responses to other diseases, but that this different response is deteriorating).

${ }^{8}$ More coercive policies have been adopted than is commonly appreciated. See Scott Burris, Public Health, "AIDS Exceptionalism," and the Law, 27 J. MARSHALL L. REV. 251, 253 (1994) (noting the governmental activity designed to curb the spread of HIV). See also text accompanying notes 62-67 infra. 
prevent and contain bioterrorism, but to preserve individual interests in the event of a misuse of governmental powers.

\section{LEGAL RESPONSES TO BIOTERRORISM}

Since ancient times, human beings have been known to use disease to injure their enemies. ${ }^{9}$ During the middle ages, soldiers threw the bodies of plague victims over the walls of enemy cities. ${ }^{10}$ During the French and Indian Wars, the English gave blankets exposed to smallpox to enemy Indian troops. ${ }^{11}$

Legal responses to biological warfare and bioterrorism are more recent. ${ }^{12}$ In 1925 the Geneva Protocol banned the use of biological weapons in war by its signatories ${ }^{13}$ (although the United States signed the Protocol in 1925, it did not ratify the treaty until 1975). ${ }^{14}$ In 1972 the Biological and Toxin Weapons Convention banned the development, production and stockpiling of biological weapons. ${ }^{15}$ As part of its implementation of the Convention, in 1989 Congress passed the Biological Weapons Anti-Terrorism Act, ${ }^{16}$ which criminalized the possession or use of biological weapons. In 1996 the Antiterrorism and Effective Death Penalty Act filled some of the gaps left by the 1989 Act by strengthening its criminal provisions and tightening the regulation of the transfer and shipment of potentially hazardous biological material. ${ }^{17}$ In addition, Congress turned its attention to bioterrorism once again in 2000, empowering the Secretary of Health and Human Services to make grants and enter into contracts to respond to

9 See JUdith Miller et AL., Germs: Biological WeAPONS AND AMERICA's SECRET WAR, 37-38 (2001) (explaining several uses of disease to harm opponents during warfare throughout history).

${ }_{10} I d$.

11 Id. at 38.

12 For the purposes of this article, I will rely upon the term "bioterrorism" to refer to any intentional use of a pathogen or biological toxin to harm or kill a human being. The distinction between biological warfare, use of biological weapons to commit an "ordinary crime," and bioterrorism, are subject to debate and not relevant for this purposes of this discussion.

${ }_{13}$ Protocol for the Prohibition of the Use in War of Asphyxiating Poisonous or Other Gases, and of Bacteriological Methods of Warfare, June 17, 1925, 26 U.S.T. 571, 94 L.N.T.S. 65, 67 [hereinafter Geneva Protocol.]

${ }_{14}$ Geneva Protocol, supra note 13, at 26 U.S.T. at 571-72.

${ }^{15}$ Convention on the Prohibition of the Development, Production and Stockpiling of Bacteriological (Biological) and Toxin Weapons and on their Destruction, Apr. 10, 1972, 26 U.S.T. 583, 1015 U.N.T.S. 163.

${ }_{16} 18$ U.S.C. $\S \S 175-78$ (2002).

${ }^{17} \mathrm{Id}$. at $\S 175(\mathrm{~b})$. 
a public health emergency and establishing a workgroup on bioterrorism. $^{18}$

Nevertheless as concerns about terrorism and bioterrorism intensified in the $1990 \mathrm{~s},{ }^{19}$ commentators increasingly pointed to deficiencies in U.S. law as part of the problem. For example, in March 2001, Juliette N. Kayyem, Executive Director of the Executive Session on Domestic preparedness at the John F. Kennedy School of Government, surveyed U.S. laws that applied to bioterrorism and concluded that "[t]here needs to be a clearer understanding of what the rules are. The law is not, and should not be, an impediment to protecting life."20 Likewise in a September 2001 article, undoubtedly written before the September 11 attacks, Professor David P. Fidler wrote that "the American legal system is simply not designed to deal with such a complex and insidious act of violence." 21

It was in response to the urgency created by September 11 and the anthrax attacks, as well as the perception that inadequate laws undermined the nation's ability to respond to bioterrorism that the CDC commissioned the Center to draft the Model Act. According to Secretary of Health and Human Services Tommy Tompson, "[w]e need[ed] not only a strong health infrastructure and a full stockpile of medical resources, but also the legal and emergency tools to help our citizens quickly." ${ }^{22}$ The Model Act's chief drafter, Professor Lawrence 0. Gostin concurred saying that the act was needed because "[c]urrent public health laws are too highly antiquated and inadequate to ensure

${ }^{18}$ See Public Health Threats and Emergencies Act of 2000, 42 U.S.C. $\S$ 247(a) (2000) (referring to the powers of the Secretary of Health and Human Services in an emergency).

19 Many factors help explain the increasing salience of bioterrorism in the 1990s. These include the 1993 bombing of the World Trade Center, the discovery of the massive bioweapons program run by the Soviet Union, as well as the program run by Iraq, and the discovery that the Japanese cult, Aum Shunrikyo experimented with biological weapons before using sarin gas to attack to the Tokyo subway system. For a full discussion of these and other events, see MILLER ET AL., supra note 9.

${ }^{20}$ Juliette N. Kayyem, U.S. Preparation for Biological Terrorism: Legal Limitations and the Need for Planning, BCSIA Discussion Paper 2001-4, ESDP Discussion Paper ESDP-2000-02, John F. Kennedy School of Government, Harvard University, March 2001 (analyzing current laws and their ability to also cover terroristic acts), available

http://ksgnotes 1 .harvard.edu/BCSIA/Library.nsf/pubs/2001ESDP2.

${ }^{21}$ David P. Fidler, The Malevolent Use of Microbes and the Rule of Law: Legal Challenges Presented by Bioterrorism, 33 CLINICAL INFECTIOUS DISEASES 686 (2001) (explaining how bioterrorism could have a negative effect on the rule of law in the United States), .pdf file available at $\mathrm{http} / /$ www.journals.uchicago.edu/CID/journal/contents/v33n5.text.htm.

${ }^{22}$ Justin Gillis, States Weighing Laws to Fight Bioterrorism, WASH. POST, Nov. 19, 2001, at A-1. 
a strong and effective response to bioterrorism ... [Public health laws] tend to be highly inadequate, confusing and contradictory even within states there's an inconsistent response."23

In response to this perceived need, the Model Act seeks first and foremost to clarify and rationalize public health law. In the tradition of the uniform law movement, ${ }^{24}$ the drafters and their sponsors sought to provide states with a model act that would put in one place all state laws pertaining to public health emergencies. ${ }^{25}$ And, the Act sought to ensure that states would have sufficient "authority" to deal with the threat of bioterrorism. As the Model Act's findings state, "government must do more to protect the health, safety, and general well being of its citizens." 26

The key provisions in the Act for providing the state with the authority to "do more" are found in Articles III, IV, and V, which enable the Governor to declare a "state of public health emergency" 27 thereby triggering "special powers." 28 Under the Model Act, the Governor

${ }^{23}$ Matt Mientka, CDC Releases Model Bioterroism Law, U.S. MEDiCINE INFORMATION CENTER (Dec. 2001), at http://www.usmedicine.com/article.cfm?articleID $=314 \&$ issueID $=33$ (last visited Oct. 24, 2002).

24 See generally, James G. Hodge, Jr., Bioterrorism Law and Policy: Critical Choices in Public Health, 30 J.L. MED. \& ETHICS 254 (2002) (explaining need for uniform collaborative effort between state, local and federal government organizations to protect the public from bioterrorism); Lorena Matei, Quarantine Revision and the Model State Emergency Health Powers Act: "Laws for the Common Good," 18 SANTA ClaRA COMPUTER \& HiGH TECH. L.J. 433 (2002) (arguing for implementation of a comprehensive law to protect citizens from bioterrorism).

${ }^{25}$ See Lawrence O. Gostin et al., The Model State Emergency Health Powers Act: Planning for and Response to Bioterrorism and Naturally Occurring Infectious Diseases, 288 JAMA $622,625-26$ (2002). The sponsors of the Act did note that the Model Act was just a model, that each state should use it as a template for discussion and review of their own laws, and that it was appropriate for states to make individual adjustments. Nevertheless, the sponsors have pointed to the advantages of consistency across state boundaries. See also George J. Annas, Bioterrorism, Public Health, and Civil Liberties, 346 NEW ENG. J. MED. 1337, 1341 (Apr. 25, 2002) (explaining the need for new public health legislation relating to bioterrorism and how the Model State Emergency Health Act will not suffice). Given the ability of bioterrorism to cross state boundaries, the viability of relying upon state as opposed to federal laws is questionable.

${ }^{26}$ MODEL ACT, supra, note 3, at $\S 102$ (a).

${ }^{27}$ Id. at $\S 401$.

${ }^{28}$ Id. at $\S 403(\mathrm{a})$, Article $\mathrm{V}$. The Model Act also has provisions that apply prior to an emergency. For example, Article II of the Act requires the Governor to appoint a commission charged with developing a "public health emergency plan." Id. at $\S \S 201,202$ (emphasis omitted). The Act, however, does not require the state to actually implement any elements of the plan. In addition, Article II of the Act requires health care providers, coroners, and medical examiners to report "any illness or 
may declare a "state of public health emergency" upon the occurrence of an

imminent threat of an illness or health condition that:

(1) is believed to be caused by any of the following:

(i) bioterrorism;

(ii) the appearance of a novel or previously controlled or eradicated infectious agent or biological toxin;

(iii) [a natural disaster;]

(iv) [a chemical attack or accidental release; or]

(v) [a nuclear attack or accident]; and

(2) poses a high probability of any of the following harms:

(i) a large number of deaths in the affected population;

(ii) a large number of serious or long-term disabilities in the affected population; or

(iii) widespread exposure to an infectious or toxic agent that poses a significant risk of substantial future harm to a large number of people in the affected population. ${ }^{29}$

Importantly, the Governor may declare such a state even "without consulting with the public health authority or other experts when the situation calls for prompt and timely action." state of emergency may continue for thirty days, whereupon the Governor (presumably again without consulting with anyone) may renew the declaration for another thirty days. ${ }^{31}$ This process apparently can continue ad infinitum although at any time the legislature may termi-

health condition that may be potential causes of a public health emergency." $I d$. at $\S$ 301(a). Pharmacists are also required to "report any unusual or increased prescription rates, unusual types of prescriptions, or unusual trends in pharmacy visits that may be potential causes of a public health emergency." Id. at $\S 301(\mathrm{~b})$. But see Annas, supra note 25, at 1340 (criticizing what the Model Act actually requires and the potential privacy implications of the requirement). The uncertainty as to what that actually requires, and the potential privacy implications of the requirement, have elicited significant criticism.

${ }^{29}$ MoDEL ACT, supra note 3, at $\S 104(\mathrm{~m})$ (emphasis omitted). The sections in brackets are meant to offer states the choice to expand the category of public health emergencies beyond bioterrorism, if they desire. See Letter of Lawrence O. Gostin, December 21, 2001 (on file with author).

${ }^{30}$ MODEL ACT, supra note 3 , at $\S 401$.

${ }^{31} I d$. at $\S 405(\mathrm{~b})$. 
nate the declaration if it finds that the "illness or health condition that caused the emergency does not or no longer poses a high probability of a large number of deaths in the affected population, a large number of incidents of serious permanent or long-term disability in the affected population, or a significant risk of substantial future harm to a large number of people in the affected population."32 Hence a state of emergency can continue without any legislative affirmation indefinitely unless a majority of the legislature votes to repeal it. ${ }^{33}$

Once a declaration is made, the Model Act gives the Governor and the public health agency extraordinary powers. ${ }^{34}$ Briefly, the declaration gives the Governor authority to "[s]uspend the provisions of any regulatory statute prescribing procedures for conducting State business, or the orders, rules and regulations of any State agency, to the extent that strict compliance with the same would prevent, hinder, or delay necessary action . . . by the public health authority." would also permit the Governor to mobilize the militia into service. ${ }^{36}$ In addition, the public health authority would be authorized to close or decontaminate facilities, ${ }^{37}$ to require health care facilities to provide services, ${ }^{38}$ and to require other facilities (the nature of which is undefined) to provide a wide variety of services to the state. ${ }^{39}$

${ }^{32} I d$. at $\S \S 405(\mathrm{~b})$, (c). It is an interesting question whether such a legislative veto is constitutional under all state constitutions. Cf., INS v. Chadha, 462 U.S. 919 (1983) (holding that federal legislative veto violates U.S. Constitution).

${ }^{33}$ The Model Act is unclear as to whether the declaration or its repeal is reviewable by a court. Although the Act provides for immunity for the state and its officials for injuries or damages caused by the declaration (except when there is gross negligence or willful misconduct), it says absolutely nothing about reviewability and the possibility of prospective injunctive relief. Presumably many state courts would find that they have the power to review such orders. Indeed, they may find that the denial of any possibility of review raises grave questions under the due process clause of the $14^{\text {th }}$ amendment as well as state constitutional provisions guaranteeing access to the courts. See, e.g., Heather Brann, Utah's Medical Malpractice Prelitigation Panel: Exploring State Constitutional Arguments Against a Nonbinding Inadmissible Procedure, 2000 UTAH L. REV. 359, 365-67 (2001) (applying due process clause and state open courts provision to pre-litigation panels in medical malpractice cases).

${ }^{34}$ See Annas, supra note 25, at 1338, 1340. See also Jennifer King, Power Grab: The States in a State of Emergency. The Model Emergency Health Powers Act, American Legislative Exchange Council Issue Analysis (Jan. 2002) (discussing the key points of the Model Emergency Health Powers Act), at http://www.alec.org/meSWFiles/pdf/0202.pdf.

${ }_{35}$ MoDEL ACT, supra note 3 , at $\S 403(\mathrm{a})(1)$

${ }^{36} I d$. at $\S 403(\mathrm{a})(4)$.

${ }^{37}$ Id. at $\$ 501(\mathrm{a})$.

${ }^{38} I d$. at $§ 502(\mathrm{~b})$.

${ }^{39}$ See id. at $\S \S 503(\mathrm{~b})$, (c) (noting that the services must be "reasonable and necessary to respond to the public health emergency"). 
The most interesting provisions, however, authorize the state to exert broad coercive powers over individuals, once a declaration of emergency has been made. First, the public health authority may perform physical examinations and/or tests "necessary for the diagnosis or treatment of individuals." ify what types of tests may be performed, or whether the examinations need to have anything to do with the health threat instigating the declaration, a state of emergency would presumably authorize the public health authority to perform almost any diagnostic test on anyone. Thus a public health authority acting in bad faith would have the lawful authority to use a public health threat as an excuse to perform mandatory HIV tests! Under the Act, an individual's refusal to permit this examination might justify isolation if the authority was uncertain if the individual was infected. ${ }^{41}$

Once a public health emergency has been declared, the public health authority would also have the power to vaccinate and treat individuals. ${ }^{42}$ Individuals who are "unable or unwilling" to submit to these procedures "for reasons of health, religion, or conscience" may be subject to isolation and quarantine. ${ }^{43}$ What happens to people who refuse to submit for other reasons (such as suspicion of public authorities) is not made clear.

The isolation and quarantine provisions are undoubtedly among the most central in the act. ${ }^{44}$ Under the Model Act, isolation and/or

40 MODEL ACT, supra note 3, at $\S 602$.

${ }^{41} I d$. at $\$ 602$ (c). Although the Act would seem to permit the public health authority to conduct almost any kind of diagnostic test or examination, quarantine or isolation is only permitted if there is uncertainty as to whether the individual has been exposed to a contagious disease. Id. Generally, a contagious disease is one that can be transmitted by casual contact. See MERRIAM-WEBSTER's ColleGIATE DicTIONARY $249\left(10^{\text {th }}\right.$ ed. 1998). However, the Act defines a contagious disease more broadly to include any "infectious disease that can be transmitted from person to person." MODEL ACT, supra note 3, at $\S 104$ (c). Hence while HIV is not typically considered a "contagious disease," it would appear to be so within the literal meaning of the Act.

42 Id. at $\$ 603$.

${ }^{43} I d . \S \S 603(\mathrm{a})(3),(\mathrm{b})(3)$.

44 Isolation, as the term is defined by the Model Act

[I]s the physical separation and confinement of an individual or groups of individuals who are Infected or reasonably believed to be infected with a contagious or possibly contagious disease from non-isolated individuals, to prevent or limit the transmission of the disease to non-isolated individuals.

Id. at $\$ 104(\mathrm{~h})$.

Furthermore, the Model Act defines "quarantine" as:

The physical separation and confinement of an individual or groups of individuals, who are or may have been exposed to a contagious or possible contagious disease and who do not show signs or symptoms of a contagious 
quarantine is authorized when individuals refuse to submit to an examination, treatment or vaccination as discussed above, as well as when they are "the least restrictive means necessary to prevent the spread of a contagious or possibly contagious disease to others. ${ }^{45}$ Again the Model Act does not require that the "contagious disease" which is the object of the isolation or quarantine be the illness that triggered the public health emergency in the first place. Thus the appearance of anthrax, a non-contagious bioterrorist agent, could theoretically trigger isolation for HIV or hepatitis if the public health authority believed that it was the "least restrictive means necessary to spread" the infection.

The Model Act relies heavily upon judicial procedures to oversee and legitimate the use of isolation and quarantine. Within ten days of subjecting an individual to isolation or quarantine, the public health authority is required to file a petition to a court stating the reasons for the order. ${ }^{46}$ Within five days of receiving the petition, a hearing must be held, although "[i]n extraordinary circumstances and for good cause" it may be postponed for up to 10 days, meaning that the individual can be held for up to 20 days before any judicial review may occur. ${ }^{47}$ At the hearing, the court may grant the petition if "by a preponderance of the evidence, isolation or quarantine is shown to be reasonably necessary to prevent or limit the transmission of a contagious or possibly contagious disease to others. ${ }^{, 48}$ An order approving the isolation or quarantine may extend for thirty days, although the court, upon motion, may extend it for another thirty days. ${ }^{49}$ An individual may also be released upon successfully petitioning the court for an order to show cause why the individual should not be released. ${ }^{50}$ For all hearings regarding an individual's isolation and quarantine, the court must appoint counsel for the individual. ${ }^{51}$ In appropriate circumstances, cases may be consolidated. ${ }^{52}$

Concerned about the human rights and dignity of those subject to these orders, the Model Act requires the state to provide for the

disease, from non-quarantined individuals, to prevent or limit the transmission of the disease to non-quarantined individuals.

Id. at $\S 104(\mathrm{o})$.

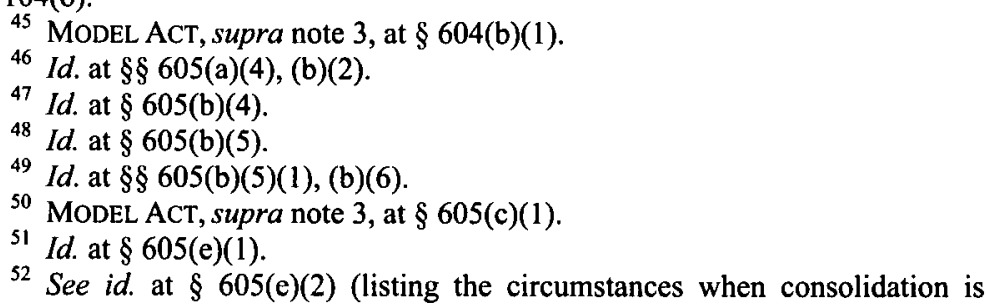
proper). 
"needs" of individuals subject to the order, by providing them with at least "adequate food, clothing, shelter, means of communication . . . medication, and competent medical care." ${ }^{.53}$ Interestingly, the Act does not explicitly require the state to provide for the economic consequences, such as loss of wages or unemployment, that an individual may face due to an isolation or quarantine order, although this may perhaps be included as part of an individual's "needs." Likewise, the Act does not explicitly obligate the state to care for an affected individual's dependants. Moreover, the stringent immunity provisions of the Model Act would appear to foreclose the possibility of any damage remedy for the state's failure to abide by some of those provisions, as well as any compensation for any economic or other injuries that may result from inappropriate or unnecessary isolation. ${ }^{54}$

\section{II. "AIDS EXCEPTIONALISM"}

It is not surprising that the advent of a frightening, seemingly new public health menace has prompted consideration of coercive measures. Throughout history, new plagues have been met with restrictions upon individual liberties. Sometimes this has been because such restrictions are the only or most effective way to preserve the community given the circumstances. Too often, however, the reliance on coercion has been unnecessary and ineffective and in hindsight can be recognized as nothing more noble than the scapegoating, if not vilification of marginalized groups. ${ }^{55}$ So it was with AIDS.

The arrival of a deadly and terrifying new disease, transmitted sexually, and associated in the public's mind with homosexuals elicited cries to remove, isolate, and even brand those who were infected. $^{56}$ Today we may forget that in the 1980s HIV positive school children were commonly cast out of their classroom, but such was the state of fear when Ryan White became a well-recognized name. ${ }^{57}$ Indeed, surveying the state of public opinion in 1987, Professor Gostin along with his co-author Andrew Ziegler wrote that

${ }^{53} I d$. at $\S 604(\mathrm{~b})(6)$.

${ }^{54} \mathrm{Id}$. at $\S 804(\mathrm{a})$.

${ }^{55}$ Wendy E. Parmet, AIDS and Quarantine: The Revival of an Archaic Doctrine, 14 HofsTRA L. REv. 53, $55-58$ (1985); Guenter B. Risse, Epidemics and History: Ecological Perspectives and Social Responses, in AIDS: THE BURDENS OF HISTORY 33 (Elizabeth Fee and Daniel M. Fox eds., 1988).

${ }^{56}$ Parmet, supra note 55, at 53-54.

${ }^{57}$ See Wendy E. Parmet \& Daniel J. Jackson, No Longer Disabled: The Legal Impact of the New Social Construction of HIV, 23 AM. J.L. \& MED.7, 10 (1997) (discussing Ryan White's plight against discrimination based on his HIV positive status). 
There is some public support for restricting the liberty and autonomy of HIV-infected people. In five national public opinion polls conducted between September 1985 and November 1986, 28 to 54 percent of the respondents favored 'quarantine' of people with AIDS in 'special places to keep them away from the general public.'

They then went on to discuss the various proposals taken up by state legislatures to increase state authority to confine HIV positive individuals. $^{59}$

Perhaps the most serious and difficult debate about the use of coercive powers and HIV concerned the use of wide-scale mandatory testing. ${ }^{60}$ For many reasons, this was never implemented. No doubt, the timing of the HIV epidemic played some role in the initial rejection of mandatory testing. Arriving after the Civil Rights movements, Watergate, the birth of the gay rights movement and even the revelations about the Tuskegee experiments, HIV made its appearance at a time when the public was especially sensitive to claims of individual rights and particularly skeptical of government authority. But even more important than the zeitgeist, perhaps, was the reality that given the fact that HIV was transmitted by private behaviors, and that an individual remained infectious throughout his or her life, it was difficult to see how mandatory testing could aid efforts to thwart the disease's spread. Rather, by the late 1980 s most public health officials had come to believe that the trust of those infected and the cooperation of communities at risk was key to protecting the public against HIV, and both of these could and would be undermined by the imposition of coercive measures. As Professor Samuel Bagenstos has written,

when public health officials forewent coercive measures in their responses to AIDS, their position reflected less a capture by an important interest group than a hardhearted calculation that an epidemic spread by the intimate conduct of particular segments of the community simply could not be brought un-

${ }^{58}$ Larry Gostin \& Andrew Ziegler, A Review of AIDS-Related Legislative and Regulatory Policy in the United States, 15 Law, Med. \& Health Care 5, 11 (1987).

59 See id. (noting that at the time some states had already enacted HIV isolation policies, while others were still considering it).

${ }^{60}$ For an early discussion of the issue, see Michael L. Closen et. al, AIDS: Testing Democracy - Irrational Responses to the Public Health Crises and the Need for Privacy in Serologic Testing, 19 J. MARSHALL L. REV. 836 (1986). 
der control by measures that failed to pay attention to the interests of those segments of the community. ${ }^{61}$

Although by the late 1980 s, a broad consensus had rejected the use of broad-scale mandatory testing and a variety of other coercive measures (such as the exclusion of children from schools), the debate continued about the more limited application of coercive powers. ${ }^{62}$ For example, in 1991 Dr. Marcia Angell editorialized in the New England Journal of Medicine for the mandatory screening of pregnant women and infants. ${ }^{63}$ Writing in the same issue, Ronald Bayer, also counseled for the reconsideration of more "traditional" public health powers. ${ }^{64}$ Arguing that HIV had been treated "exceptionally," Bayer wrote:

In the first years of the AIDS epidemic, U.S. officials had no alternative but to negotiate the course of AIDS policy with representatives of a well-organized gay community and their allies in the medical and political establishments. In this process, many of the traditional practices of public health that might have been brought to bear were dismissed as inappropriate. As the first decade of the epidemic came to an end, public health officials began to reassert their professional dominance over the policy-making process and in so doing began to rediscover the relevance of their own professional traditions to the control of AIDS. ${ }^{65}$

${ }^{61}$ Samuel R. Bagenstos, The Americans with Disabilities Act as Risk Regulation, 101 COLUM. L. REV. 1479, 1503 (2001).

${ }_{62}$ The debate has also never ended as to whether HIV status alone should be a reportable disease. For a discussion of this issue, see Lawrence O. Gostin \& James G. Hodge, Jr., The "Names Debate": The Case for National HIV Reporting in the United States, 61 ALB. L. REv. 679 (1998).

${ }^{63}$ Marcia Angell, A Dual Approach to the AIDS Epidemic, 324 New ENG. J. MED. 1498, 1499-1500 (1991). The question of whether pregnant women or newborns should be subject to mandatory testing has never gone away. Although the CDC formulated a policy calling for routine counseling and voluntary testing of all pregnant women, FY 1995 Epidemiologic Research Studies of Acquired Immunodeficiency Syndrome (AIDS) and Human Immunodeficiency Virus (HIV) Infection, 60 Fed. Reg. 35405, 35406 (July 7, 1995), New York State passed the nation's only law requiring testing of newborns. N.Y. PUBlic HealTH LAW $\$ 2500-f$ (McKinney 2002). For more on the current debate, see Leslie Ayers, Note,-Is Mama a Criminal? -An Analysis of Potential Criminal Liability of HIV-Infected Pregnant Women in the Context of Mandated Drug Therapy, 50 DRAKE L. REV. 293, 297-98 (2002).

${ }^{64}$ Bayer, supra note 7, at 1502-04.

${ }^{65} \mathrm{Id}$. at 1502-04. The claim that political necessity led to the rejection of traditional public health approaches in the early years of the HIV epidemic also ap- 
Bayer and Angell were not alone. Lee Reichman, director of the National Tuberculosis Center, stated " $[t]$ raditional public health is absolutely effective at controlling infectious disease. It should have been applied to AIDS from the start, and it wasn't. Long before there was AIDS, there were other sexually transmitted diseases, and you had partner notification and testing and reporting. This was routine public health at its finest. ${ }^{.96}$

Although some commentators at the time questioned the "AIDS exceptionalism" thesis, ${ }^{67}$ by the mid-to-late 1990 s many scholars and public health officials had begun to question the rejection of coercive measures vis-a -vis HIV. ${ }^{68}$.Thus when multi-drug resistant tuberculosis appeared in New York in the early 1990s, many experts concurred on the need to institute mandatory treatment and isolation (as well as directly observed therapy). ${ }^{69}$ The efficacy of those methods in the "war" against MDR-TB seemed to vindicate the exceptionalist thesis which premised the importance of restricting individual liberties in the name of public health. ${ }^{70}$

The legal corollary to the exceptionalism thesis was that the police power provided states with the authority to restrict individual liberty in the name of public health. Just as the HIV exceptionalists believed that restrictions on individual liberty were key to public health's ability to control communicable diseases, public health scholars viewed liberty-restraining regulations as the sine qua non of public health law. In 1999 Professor Gostin along with his colleagues Professors Burris and Lazzarini wrote: "A reliance on coercive reactive

pears in Bayer, supra note 1, at 21.

${ }^{66}$ Chandler Burr, The AIDS Exception: Privacy v. Public Health, THE ATLANTIC MONTHLY, June 1997, at 57, 66.

${ }^{67}$ See Burris, supra note 8, at 252 (noting that AIDS exceptionalism "never quite existed").

${ }^{68}$ See Burr, supra note 66 (providing examples of advocates for traditional, coercive measures).

${ }^{69}$ See Teri Flowers, Quarantining the Noncompliant TB Patient: Catching the "Red Snapper," 28 J. HEALTH \& HOSP. L. 95 (1995) (advocating quarantining of tuberculosis patients); Patricia C. Kuszler, Balancing the Barriers: Exploiting and Creating Incentives to Promote Development of a New Tuberculosis Treatment, 71 WASH. L. REV. 919, 930-37 (1996); Karen H. Rothenberg \& Elizabeth C. Lovoy, Something Old, Something New: The Challenge of Tuberculosis Control in the Age of AIDS, 42 BUFF. L. REV. 715, 729-31 (1994) (discussing tuberculosis treatment and experts' desire to institute mandatory isolation and treatment as done in the $19^{\text {th }}$ and early $20^{\text {th }}$ centuries).

${ }^{70}$ See Thomas R. Frieden et al., Tuberculosis in New York City - Turning The Tide, 333 NEw ENG. J. MED. 229, 229-31 (1995) (illustrating the great success of using directly observed therapy and treatment completion in controlling the spread of tuberculosis). 
control methods - particularly nuisance abatement, quarantine, and isolation - can be said to form the deepest layer of American disease control law, a layer that is often invisible, but that still shapes the structure of the statutory landscape."71 Likewise in his 2000 opus, Public Health Law: Power, Duty and Restraint, Professor Gostin again noted the central role that coercion of individuals plays in public health promotion, stating that "[ $t]$ he study of the coercive powers of the state is a staple of what we call public health law.,"72

Professor Gostin's appreciation of the states' coercive powers has never been uncritical. Indeed, as far back as 1986 he criticized the antiquated nature of many state laws, noting that they often fail to reflect contemporary understandings of both epidemiology and constitutional law. ${ }^{73}$ In 1999 he, along with Professors Lazzarini and Burris wrote:

The most striking characteristic of state disease control law, and the one that underlies most of its defects, is its overall antiquity ...

Certainly, old laws are not necessarily bad laws. A wellwritten statute may remain useful, efficacious, and constitutional for many decades. Nevertheless, old public health statutes that have not been substantially altered since their enactment are often outmoded in ways that directly reduce both their efficacy and their conformity with modern standards. These laws often do not reflect contemporary scientific understandings of disease, current treatments of choice, or constitutional limits on states' authority to restrict individual liberties. $^{74}$

Thus long before the terrible events of the fall 2001, Professor Gostin and many others had come to believe that despite prevailing HIV-policies, the core to public health law was the states' coercive powers. These powers, however, were seen as in serious need of up-

7 Lawrence O. Gostin et al., The Law and the Public's Health: A Study of Infectious Disease Law in the United States, 99 CoLUM. L. REV. 59, 102 (1999).

72 Lawrence O. Gostin, Public Health Law: Power, Duty, Restraint 19 (2000).

${ }^{73}$ Lawrence O. Gostin, The Future of Public Health Law, 12 AM. J.L. \& MED. 462, 463-71 (1986). See also William J. Curran, Mary E. Clarke \& Larry Gostin, AIDS: Legal and Policy Implications of the Application of Traditional Disease Control Measures, 15 LAW MED. \& HEALTH CARE 27 (1987) (stating concerns about traditional ways of handling diseases as applied to the AIDS epidemic).

${ }^{74}$ Gostin et al., supra note 71, at 102-06 (citations omitted) 
dating. ${ }^{75}$ But by revising them to reflect "modern" understandings of disease and law, these scholars believed that states could more effectively protect public health by restraining individuals while respecting their legal rights. These three axioms that public health law is most fundamentally about the restraint of individual liberties, that it requires modernization, and that modernization can ensure the protection of individual rights while restraining those rights - animate the Model Act. The question remains: how valid are these premises?

\section{THE ROLE OF COERCIVE POWERS IN PUBLIC HEALTH PROTECTION}

There can be no doubt that the restraint of individuals, especially via quarantine and isolation, has long played an important role in public health law. During the middle ages, lepers were subject to isolation throughout Europe. ${ }^{76}$ On these shores, quarantines against smallpox were instituted as far back as $1622 .^{77}$

There can also be little doubt that courts have generally upheld the use of isolation and quarantine for public health goals. ${ }^{78}$ When communities were threatened by devastating epidemics, judges were loathe to question actions that were taken in the name of public health. ${ }^{79}$ Thus in the famous case of Jacobson v. Massachusetts, which upheld a law requiring vaccination against smallpox, the Supreme Court of the United States said:

Upon the principle of self-defense, of paramount necessity, a community has the right to protect itself against an epidemic of disease which threatens the safety of its members ... [I]t is equally true that in every well-ordered society charged with the duty of conserving the safety of its members the rights of the individual in respect of his liberty may at times, under the pressure of great dangers, be subjected to such restraint, to be

${ }^{75}$ See Gostin et al., supra note 25, at 623. The drafters of the Model Act repeated that point in 2002. Echoing the 1999 article by Gostin, Lazzarini and Burris, they wrote, "[S]tate public health statutes frequently are outdated and were built up in layers during the $20^{\text {th }}$ century in response to each new disease threat. Consequently, these laws often do not reflect contemporary scientific understandings of disease (e.g., surveillance, prevention, and response) or legal norms for protection of individual rights."

76 Parmet, supra note 55, at 55.

${ }^{77}$ Id. at 56 .

${ }^{78}$ Id. at $59-66$.

${ }^{79}$ Id. at 64-69. However, U.S. judges often did engage in a limited form of review, determining whether public health authorities had exceeded the scope of their authority and had not acted arbitrarily and without reason. See id. 
enforced by reasonable regulations, as the safety of the general public may demand. ${ }^{80}$

The ubiquity and legality of quarantine and isolation, however, do not in themselves establish that they have been or ought to be seen as the core to public health law in general or central to our efforts to confront bioterrorism or many emerging threats. ${ }^{81}$ With respect to history, the focus on isolation and quarantine of individuals overlooks the fact that historically quarantines were probably more often instituted against cargo vessels than against individuals. ${ }^{82}$ Indeed, in U.S. constitutional law, the police power doctrine developed significantly in contests over the government's ability to regulate commerce. ${ }^{83}$ In the $19^{\text {th }}$ century it was often business interests, not advocates for individual rights, who challenged the authority of public health boards. ${ }^{84}$

These points are salient not because they question the ability of government to restrain the liberty of individuals, but because they should remind us that public health, in practice and in law, generally has had as much or more to do with regulatory efforts to shape the market than to restrain individuals. In the $19^{\text {th }}$ century, after all, the great early steps taken by public health focused on the supply of clean water and wholesome foods. $^{85}$ In these instances government restrained liberty, but it was not the personal liberty of individuals to

${ }^{80}$ Jacobson v. Massachusetts, 197 U.S. 11, 27, 29 (1905).

${ }^{81}$ For arguments that quarantine and isolation would likely be fairly useless under most bioterrorism scenarios, see Joseph Barbera et al., Large-Scale Quarantine Following Biological Terrorism in the United States, Scientific Examination, Logistic and Legal Limits, and Possible Consequences, 286 JAMA 2711 (Dec. 2001).

82 See William J. NovaK, The People's Welfare: LaW and Regulation IN NINETEENTH-CENTURY AMERICA 204-05 (1996) (explaining the frequent use of maritime quarantines on vessels arriving on American shores). See also Sylvia N. Tesh, Miasma and "Social Factors" in Disease Causality: Lessons from the Nineteenth Century, 20 J. HEALTH POL. POL'Y \& L. 1001, 1005 (1995) (discussing how quarantines not only interfered with commerce but he interest of the people).

${ }^{83}$ Wendy E. Parmet, After September 11, Rethinking Public Health Federalism 30 J.L. MED. \& ETHICS 201, 202-03 (2002).

${ }^{84}$ NoVAK, supra note 82 , at 209 . On the other hand, business interests also sometimes favored public health regulations, for example a historian of food inspection laws claims that the livestock and packing industries pressed for regulations so that European countries would open their markets to American meat. VIVIAN WISER, U.S. Dep't of Agric, Meat and PoUltry Inspection in the United States DEPARTMENT OF AGRICULTURE.

${ }^{85}$ See George Rosen, A History of Public Health 216-16 (expanded ed., The Johns Hopkins Univ. Press 1993) (1958) (discussing the causes of public health reform in the $19^{\text {th }}$ century). See also Wendy E. Parmet, From Slaughter-House to Lochner: The Rise and Fall of the Constitutionalization of Public Health, 40 AM. J. LEGAL HIST. 476, 489 (1996) (stating the importance of clean water and pure food). 
control their movement or make decisions about their own health care and bodily integrity; rather it was the liberty of businesses to sell unpasteurized milk or the liberty of taxpayers to avoid supporting a public water supply.

Certainly as the germ theory and contagionism took hold and the massive epidemics of the $19^{\text {th }}$ century faded from memory, public health practitioners were more apt to see an individual who carried an infectious agent rather than filth or miasma as the source of danger. Likewise, as clinical medicine became more efficacious and more dominant, public health increasingly adopted its individualistic orientation and came to believe that identifying patients and getting them to treatment was central to its mission. ${ }^{86}$ As a result, public health advocates began to stress the virtue of contact tracing and isolation. ${ }^{87}$ But this vision of public health was never uncontested. ${ }^{88}$ Even in the heyday of the public health movement, some adherents stressed education over coercion, arguing for the need to obtain a patient's cooperation. ${ }^{89}$ Other public health notables argued that public health had to focus less on identifying and treating individuals and more on what we today would call the social conditions for health. In 1904, for example, Herman Biggs claimed that the time had come for public health to emphasize the occupational conditions that give rise to morbidity. ${ }^{90}$ Less than two decades later, C.E.A. Winslow, noted that while "[s]anitation, isolation, vaccine and serum therapy, provided the complete machinery necessary for controlling many of the acute communicable diseases; . . . it became clear that the major problem of tuberculosis required other methods for its solution." ${ }^{.91}$ He described these

${ }^{86}$ Parmet, supra note 85 , at 491 . Scott Burris has noted that the so-called traditional public health powers have been used only infrequently and have "deep roots in a medicalized approach to public health." Burris, supra note 8, at 257.

${ }^{87}$ E.g., George H. Rohe, Recent Advances in Preventive Medicine, 9 JAMA 1, 10-11 (1887) (arguing that the first requirement for dealing with an infectious disease from a "State Medicine Point of View" is notification and the second is segregation. The third requirement according to Rohe was disinfection).

${ }^{88}$ Burris, supra note 8 , at 256 (noting that the process of identifying and treating at-risk individuals had the effect of separating social reform from medical treatment in the field of public health). See also, Barbara Gutmann Rosenkrantz, Cart Before Horse: Theory, Practice and Professional Image in American Public Health, 1870-1920, J. HIST. MED. \& ALLIED SCI. 55, 66-68 (1974) (discussing problems associated with registration and tracing of tuberculosis patients as prevention of spreading the disease).

${ }^{89}$ See Rosenkrantz, supra note 88, at 63-64 (emphasizing the importance of educating the public to increase health improvements and battle diseases).

90 Herman M. Biggs, Preventive Medicine: Its Achievements, Scope, and Possibilities, 65 MED. RED, 956 (1904).

91 C.E.A. Winslow, The Evolution and Significance of the Modern Public 
methods as including the organization of sanatoriums and dispensaries, the development of ambulatory care and home visits, and most especially a campaign of public education. ${ }^{92}$ It might also include, he suggested, the establishment of some system of health care financing to permit the poor to pay for the kind of medical care that public health advocated. ${ }^{93}$

In the twentieth century, the jurisdiction of public health fragmented. Many of the problems, and legal controls, that were once within the purview of public health boards fell to other governmental bodies, such as the Environmental Protection Agency, the Food and Drug Administration and state agencies. ${ }^{94}$ Often, these agencies focus on regulating large actors in the marketplace, not individuals. But that does not mean that such agencies do not "do" public health. They do. As a result, the claim that coercion of individuals is core to public health is in part an artifact of the divestment of many public health functions to other agencies.

All of this is not to deny a role, even a vital one, for the restriction of individual liberty in times of public health crisis. But it is to question the claims of the AIDS exceptionalists that such restraints are core to public health powers. Rather, other forms of government activity, including especially the regulation of goods and services and the formation of government services, such as the provision of clean water and the inspection of food supplies, are far more apt candidates for the title of core public health powers (even if some of these activities are no longer carried out by boards of health).

This suggests that the assumption of the drafters of the Model Act that updating and expanding the government's ability to coerce individuals is central to confronting bioterrorism may well be misplaced. There is no evidence to conclude that public health in the past has been most successful when it has relied primarily upon individual coercion and there is little reason to believe that such a policy would be the most effective approach were we faced with another bioterrorist incident. ${ }^{95}$ Indeed, if history teaches us anything about the use of such

Health Campaign, J. PUB. Health POL'Y, at 50 (3d printing 1984).

$92 \mathrm{Id}$. at 52 .

93 Id. at 61-62.

9421 U.S.C. $\$ 393$ (2002); Reorg. Plan No. 3 of 1970, 35 Fed. Reg. 15623 (1970), reprinted in 5 U.S.C. app. 1 at 389 (1996). See RoSEN, supra note 85, at 21516 (discussing the establishment of voluntary health association to improve public health); James G. Hodge, Jr. Implementing Modern Public Health Goals Through Government: An Examination of New Federalism and Public Health Law, $14 \mathrm{~J}$. ConTEMP. Health L. \& Pol'y 93, 101-03 (1997).

95 Barbera et al., supra note 81 , at $2713-14$. This is not to question the appropriateness of applying the coercive authority of the criminal law to the perpetrators 
"traditional powers" it is that they are often, especially in crises, misused, sacrificing the rights of especially vulnerable individuals often for little or no public health benefit. ${ }^{96}$ Whether that might happen under the Model Act depends, in large part, upon whether the drafters are correct in assuming that a modern statute, incorporating contemporary legal standards, can prevent the abuses of public health authority so common in history. It is to this question that I now turn.

\section{THE ROLE OF LAW IN PROTECTING INDIVIDUAL RIGHTS}

A central tenet of the Model Act is that a modern, carefully drafted statute, providing for current standards of due process can help avoid the abuses of public health authority that have occurred in prior epidemics. Two premises are implicit in this tenet. First, that a modern statute will clarify ambiguity and prevent misuses of legal authority. ${ }^{97}$ Second, that contemporary legal standards provide meaningful protections against abuses of authority. Each deserves brief discussion.

Responding to Professor Gostin's long-articulated belief that public health statutes are in a shambles and badly in need of updating, the Model Act seeks to resolve issues of authority and rights by providing clear and contemporary language. But while Professor Gostin and others have demonstrated by their review of state statutes that many state public health laws are old and confusing, there is little evidence to conclude that they have impeded public health protection. ${ }^{98}$ Moreover, it is by no means clear that any new code could provide greater clarity and legal certainty than do current statutes. Indeed, there are many reasons to doubt that it could.

of bioterrorism. My focus here is on the application of coercion to victims of bioterrorism.

${ }^{96}$ For a discussion of how public health officials in San Francisco in the early 1900 s came to equate bubonic plague with race and as a result imposed a quarantine on Chinatown, see NAYAN SHAH, CONTAGIOUS DIVIDES: EPIDEMICS AND RACE In SAN FranCisCo's ChINATOWN 120-57 (2001).

97 See Gostin et al., supra note 25 , at $623-24$. The drafters also hope that a modern statute will clarify the vigorous nature of authority, when it is needed.

${ }_{98}$ For example, in a recent article on New York's initial response to the West Nile Virus, Wilfredo Lopez, counsel for the Department of Health noted that "the existing authority of the Board of Health, which in the abstract may seem vague or ambiguous, is still sufficiently flexible, effective, and amazingly powerful when appropriately applied to a particular situation." Wilfredo Lopez, West Nile Virus in New York City 92 AMER. J. Pub. Health 1218, 1221 (2002). According to Lopez, the West Nile experience teaches the need for greater understanding of existing laws and greater cooperation among agencies and professionals. Id. 
First, although the Model Act was drafted by luminaries in the field, it has its own ambiguities. For example, as was noted above, the Act is quite unclear about what treatments and tests may be required once a public health emergency is declared. ${ }^{99}$ The Act's treatment of individuals who refuse forced vaccinations for reasons other than those provided for in the Act is also uncertain. ${ }^{100}$ Nor are the mandatory reporting requirements applicable to pharmacists crystal clear in their meaning. ${ }^{101}$

These uncertainties are not pointed out as criticism of the drafters' work. Instead, there is a significant reason to wonder whether any new code can possibly foresee and resolve all of the issues that may emerge if and when there is a major bioterrorist incident. Indeed, precisely because the drafters are writing for the unthinkable, we may well wonder whether they really can make it all that clear and certain.

To be sure, existing state public health laws do not deserve any Strunk and White awards for clarity of prose. However, when we ask "what is the law" we generally do not ask only what the statute says, but also what the courts and administrative agencies have said about it. Old laws therefore, have at least one virtue lacking in any new law: there are often judicial and administrative interpretations (not to mention shared practices and understandings that have guided agencies) that resolve some of the ambiguities and fill in some of the drafters' holes. Any new statute, precisely because it is new, lacks that annotation and thus, in some significant sense, may be more prone to ambiguity than its predecessor. The Model Act's drafters have tried to mitigate this problem by basing their language on some pre-existing state laws and providing a legislative history to each section which cites to those laws. Nevertheless, the lack of interpretative gloss may be especially problematic because doctrines precluding advisory opinions will make it difficult in many states to know precisely how states will actually interpret specific provisions new to their states until an emergency declaration is made, but that, of course, is precisely the time for which the drafters hoped to provide certainty. ${ }^{102}$

${ }^{99}$ See MODEL ACT, supra note 3, at $\S 602$ (noting that the Act only instructs that the tests "must not be such as are reasonably likely to lead to serious harm to the affected individual").

${ }^{100}$ See id. at $\S 603$ (b)(3) (listing only three reasons why individuals may not be willing to submit to vaccination).

${ }_{101}$ See id. at $\S 301$ (b) (listing when a pharmacist needs to report).

${ }^{102}$ Some states do permit their courts to offer advisory opinions. This would be especially useful, especially in states where there may be colorable claims that the Model Act violates provisions of the state constitution. See PAUL M. BATOR ET AL., Hart \& Wechsler's the Federal Courts and the Federal Process 70 (3d ed. 1988). 
Even if clarity can be obtained, however, the ability of any emergency statute to prevent abuses is worth pondering. As Professor Gostin and his colleagues have aptly stated:

The greatest risk to liberties may be that safeguards that are adequate in principle will not be practically sufficient in the face of the terror of an attack, that government officials may use a false emergency as a pretext for oppressive acts, or that social factors like race, religion, or class will influence decision makers. Racial, religious, and class bias have influence public health responses to epidemics in many instances in our past. We also must be concerned that the breakdown of civil order may include a break-down of administration in many social institutions, including the court system. The right to challenge a quarantine in court cannot be exercised if there are no court clerks or judges to accept writs or hear cases. ${ }^{103}$

The response of the Model Act's drafters to these problems is that states ought to develop contingency plans and conduct training to prepare for such emergencies. They write: "[i]n this sense, the Model Act also attempts to promote the protection of civil liberties by requiring planning and training for a public health emergency."104 However, the Act itself does not actually mandate any training; it simply requires the preparation of an emergency plan which may or may not deal with the problem adequately and may or may not ever be given vitality through training and the deployment of adequate resources. ${ }^{105}$ But even if the Act does spur training and planning aimed at ensuring the implementation of the legal procedures and guarantees the Act provides, and even if the courts were to stay open in the event of a declaration of a public health emergency, the question remains whether the Act's legal procedures can play the role the Model Act envisions for them.

The reliance upon courts to mediate the tensions between public health and individual rights also derives in part from the AIDS epidemic. Although courts reviewed public health actions prior to HIV, the AIDS epidemic was certainly the first fully litigated public health crisis. Space here precludes a full discussion of the important role that courts played in the HIV epidemic, but there can be no doubt that they played a critical role in signaling the inappropriateness of dis-

\footnotetext{
${ }^{103}$ Gostin et al., supra note 25 , at 627 .

${ }^{104} \mathrm{Id}$.

${ }^{105}$ See ModeL ACT, supra note 3, at $\S \S 202(a)(1)-(15)$ (listing the components of such an emergency plan).
} 
crimination against people who are HIV positive. ${ }^{106}$ Indeed, looking at the role that courts played during the HIV epidemic, Professor Gostin was able to write confidently about the courts' insistence that infringements on civil liberties can be undertaken only after careful consideration and when no less restrictive alternative is available. ${ }^{107}$ This substantive standard has been incorporated, with modification, into the Model Act. ${ }^{108}$

Without denying the critical role legal standards and judicial process played with respect to HIV, there are serious reasons to examine whether they can be expected to play as constructive a role in the event of a bioterrorist event. Indeed, it may be that the judiciary's initial response to HIV, not public health's rejection of coercion, is what made AIDS policy truly exceptional. In other times, judges have been far less apt to protect the rights of individuals subject to public health orders. ${ }^{109}$

Generally limitations on individual liberty made in the name of public health are imposed by public health officials. In the case of HIV, in contrast, limitations upon an individual's freedom, or discrimination, usually came not from a public health official, but from a private citizen or another governmental agency not charged with or particularly expert in public health. ${ }^{110}$ In those cases, more often than not, public health officials sided with the individual and argued that the restriction upon the individual's rights would not advance any public health goal. ${ }^{111}$ Thus when the courts in those cases safe-

106 See, e.g., Bragdon v. Abbott, 524 U.S. 624, 641 (1998) (ruling in favor of a plaintiff seeking anti-discrimination protection on the basis of disability under the ADA due to her HIV infection).

${ }^{107}$ Lawrence O. Gostin, Public Health Theory and Practice in the Constitutional Design, 11 HEALTH MATRIX 265, 306-08 (2001).

108 More specifically the Model Act uses the language of "least restrictive means" to limit the methods of isolation employed, not the actually determination of whether or not isolation or quarantine is required. Sec. $604(\mathrm{~b})(1)$ states:

Isolation and quarantine must be by the least restrictive means necessary to prevent the spread of a contagious or possibly contagious disease to others and may include, but are not limited to, confinement to private homes or other private and public premises.

When reviewing whether to grant a petition to isolate or quarantine an individual, the Model Act requires that the court determine whether the isolation or quarantine is "reasonably necessary" to prevent or limit the transmission of a contagious disease. Id. at $\S 605(\mathrm{~b})(5)$.

109 Gostin, supra note 107, at 295.

110 Thus several school boards voted to exclude children who were HIV positive. See Parmet \& Jackson, supra note 57, at 16-20 (discussing various courts' treatment of school boards' discrimination against HIV positive students).

111 See Wendy E. Parmet, The Supreme Court Confronts HIV: Reflections on Bragdon v. Abbott, 26 J.L. MED. \& ETHICS, 225, 226 (1998) (changing the role of 
guarded individual rights, they did it in a context in which public health authorities supported those rights. We cannot derive from those cases the lesson that courts can be trusted to engage in a meaningful review of public health powers, especially when those powers are exercised during an emergency.

Reliance on the HIV cases for faith in the ability of courts to serve as a check on misuse of authority may be misplaced for another reason. Times have changed. In the early years of the HIV epidemic, plaintiffs were almost always successful when they used disability discrimination laws to challenge discrimination based upon HIV status. This trend reached its zenith in 1998 in Bragdon v. Abbott, in which the Supreme Court held that the Americans with Disabilities Act may be used by a woman who was HIV positive but not overtly symptomatic with the disease. ${ }^{12}$ Since then, however, the Supreme Court has consistently narrowed its interpretation of the definition of disability under the ADA, making it ever harder for plaintiffs to demonstrate that they are "in the protected class." ${ }^{\text {"13 }}$ Perhaps even more relevant is the fact that the Court has shown an increasing willingness to defer to the decisions of regulators and even employers who have concluded that individuals with disabilities pose a health threat to themselves or others. ${ }^{114}$ While these cases would not be directly relevant to the question of how courts would review any exercise of coercive powers under the Model Act (although they would be relevant if an individual challenged the Model Act for its failure to adhere to the $\mathrm{ADA})^{115}$ they should provide reason to question whether courts can be

public health from restricting to protecting individual rights).
${ }_{112} 524$ U.S. at 641 .
113 See also Matthew Diller, Judicial Backlash, the ADA, and the Civil Rights Model, 21 BERKELEY J. EMP. \& LAB. L. 19, 22 (2000) (noting recent decisions that narrow the approach to interpreting the ADA). E.g., Toyota Motor Mfg., KY., Inc. v. Williams, 534 U.S. 184, 198 (2002) (holding that to "be substantially limited in performing manual tasks, an individual must have an impairment that prevents or severely restricts the individual from doing activities that are of central importance to most people's daily lives. The impairment's impact must also be permanent or long term"); Sutton v. United Air Lines, Inc., 527 U.S. 471 (1999).

114 See Chevron U.S.A., Inc., v. Echazabal, _ U.S. _, 122 S. Ct. 2045, 2047 (2002) (supporting the idea that the ADA allows employers not to hire disabled individuals if the employer believes the individual will be harmed); Albertson's Inc. v. Kirkinburg, 527 U.S. 555, 558 (1999); Bagenstos, supra note 61, at 1479-80 (describing the latitude given to employers and professionals by the Court when they believe disabled individuals pose safety risks).

115 An individual's ability to do so may be thwarted by the Supreme Court's ruling in Bd. of Trustees v. Garret, 531 U.S. 356 (2001) (holding that sovereign immunity bars claims against state entities under Title I of the ADA). 
relied upon to engage in a meaningful assessment of risk during the due process proceedings called for under the Model Act. ${ }^{116}$

The Act's faith in procedural due process hearings should be questioned for another reason. In recent years, the federal courts have imposed numerous procedural hurdles that make it very difficult for individuals to bring due process or constitutional claims, especially against states, who now enjoy broad sovereign immunity from federal constitutional claims. ${ }^{117}$ Moreover, while the federal courts have not disclaimed key earlier precedents establishing the right to a hearing before civil commitment, ${ }^{118}$ recent cases have demonstrated a willingness to limit to some extent the sweep of procedural protections, ${ }^{19}$

${ }^{116}$ See Lawrence O. Gostin, Impact of the ADA on the Health Care System, in IMPLEMENTING THE AMERICANS WITH DISABILITIES ACT 175, 183-84 (Lawrence O. Gostin \& Henry A. Beyer eds., 1993) (indeed, Professor Gostin has longed looked to disability law and the courts' jurisprudence there as to when individuals with disabilities create a "direct threat" to the health or safety of others as a model to be applied in public health law generally). There is little doubt that this jurisprudence has influenced the Model Act and is, to some extent, part of the "modern" legal standards imported into the Act. Recent case law under the ADA, however, should give pause as to whether these standards are as protective of individual interests as was once thought, and whether judges acting under the hurried procedures called for under the Model Act are more likely to engage in a dispassionate review than are federal judges presented with the luxury of full and unhurried review in ADA cases. Of course, isolation orders and quarantines under the Model Act will be reviewed by state as opposed to federal judges, and it may well be that they will be less deferential to those seeking to limit the rights of people who are claimed to be a threat to others than has been true in federal, ADA cases.

117 This is not relevant to the question of whether a due process hearing would be available under the Model Act, but it does suggest that the judiciary in general is less amenable to due process type claims today than it was twenty years ago. Moreover, sovereign immunity would present a problem if an individual sought to challenge the Model Act in federal court. See Erwin Chemerinsky, Against Sovereign Immunity, 53 STAN. L. REV. 1201, 1202-03, 1215-16 (2001) (noting that the Court has not indicated a willingness to relax to relax federal sovereign immunity). And the Model Act itself imposes its own brand of sovereign immunity. MODEL ACT, supra note 3 , at $\$ 804$.

${ }^{118}$ For a list of critical early cases see Vitek v. Jones, 445 U.S. 480, 491 (1980) (holding that transfer of a prisoner to a mental hospital requires a hearing before an independent decision maker); Addington v. Texas, 411 U.S. 418, 425 (1979) (discussing the need for due process protection in civil commitments); and Mathews v. Eldridge, 424 U.S. 319, 333 (1976) (emphasizing the idea that due process requires the right to be heard).

${ }^{119}$ See Heller v. Doe, 509 U.S. 312, 322 (1993) (analyzed under the Equal Protection Clause, permitting a lesser standard of proof for the commitment of mentally retarded individuals than is applied to cases involving the commitment of mentally ill individuals); United States v. Sahhar, 917 F.2d 1197, 1205-06 (9 ${ }^{\text {th }}$ Cir. 1990) (holding that a jury is not required for civil commitment under 18 U.S.C. 4246); United States v. Baker, 45 F.3d 837 (4 ${ }^{\text {th }}$ Cir. 1995) ( use of video conferencing does not violate procedural due process rights of an inmate subject to civil commitment). 
and some Supreme Court justices have even questioned whether a constitutional claim may be brought when an individual was denied a hearing prior to a civil commitment. ${ }^{120}$ To the extent that these cases limit an individual's right to due process, the Model Act should be credited with possibly granting individuals even more procedural protections than they are ensured under the Constitution. However, the courts' attitude toward recent procedural due process cases should again raise qualms about the usefulness and impact of such hearings. Courts that are so confident that public officials will "do the right thing" that they do not believe it is necessary to provide a strong degree of procedural protections are not likely to engage in a very rigorous review when hearings actually occur. ${ }^{121}$

This is not to say that access to the courts is not crucial. It remains the indelible core of the rule of law. But we should question whether the due process/anti-discrimination model of legal rights, that relies so heavily upon individual hearings and individual claims before courts, that emerged from the HIV epidemic, can be counted on in the future to play the critical role that it played with respect to HIV.

\section{RETHINKING THE ROLE OF QUARANTINE AND ISOLATION}

There is no magic bullet for bioterrorism, just as there isn't one for most public health threats. Unfortunately, protection of the public health usually requires a complex array of strategies, from public education to surveillance, from vaccine development to market controls. Most or all of them will involve law. Only a few of them will require the curtailment of individual liberties.

The sponsors and drafters of the Model Act are acutely aware of the need for a sophisticated, multi-prong approach to bioterrorism. They have never advocated that restrictions on individual rights should play the sole or even leading role in that struggle. Instead they rightly see the Model Act and the coercive powers it would provide as but a single element in a multi-tiered process. And, they have attempted to construct that process while providing for significant judicial protections for individual rights.

${ }^{120}$ E.g., Zinermon v. Burch, 494 U.S. 113 (1990) (O'Connor, J. dissenting joined by Rehnquist, C.J., Scalia, J., and Kennedy, J.) (arguing that the state's failure to follow own procedures and permit an involuntary commitment to a mental hospital without a hearing is not unconstitutional).

${ }^{121}$ Of course, again, the hearings under the Model Act will occur in state not federal court. On the other hand, they will occur in an emergency, which is not generally the case in the procedural due process context. 
Nevertheless, there is a danger that the dissemination of the Model Act may be construed by political leaders and others as "solving" the problem of legal preparedness. Today when our public health infrastructure is sorely tattered, ${ }^{122}$ and when "solutions" seem hard to envision, the clarification of coercive powers may provide an easy and relatively inexpensive fix. ${ }^{123}$

The danger brought by such a balm is not merely the illusion of false comfort. It is the potential for distraction and misdirection of priorities. By focusing on how we can update the law to do a better job of isolating and quarantining individuals, or vaccinating them without their consent, we risk overlooking the other ways that we can and should use law proactively to help prevent and prepare for bioterrorism.

One obvious candidate for legal attention is the international development and transport of dangerous pathogens and other ingredients of biological weapons. Last year, a few weeks after the unveiling of the Model Act, the Bush administration announced its rejection of international talks aimed at strengthening the 1972 Biological Weapons Convention. ${ }^{124}$ More recently, the Administration has stated that it is abandoning efforts to strengthen the Convention. ${ }^{125}$ While a full analysis of that particular international effort is beyond the purview of this paper, the point remains that there is a critical need for legal efforts to curtail the creation and shipment of biological weapons. Emergency powers designed to contain a bioterrorist outbreak by isolating individuals can never be a substitute for legal efforts designed to prevent one in the first place.

Domestically, last spring's Public Health Security and Bioterrorism Preparedness and Response Act ("PHSBPRA") undertook many important steps, greatly increasing federal funding for state and local preparedness and tightening the regulation of laboratories that use

122 COMmittee for the Study of the Future of Public Health, The FUTURE OF PUBLIC HEALTH 73-106 (1988).

${ }^{123}$ For example, last fall Governor Jane Swift of Massachusetts supported the Model Act and promised to push for its passage in her state. Justin Gills, States Weighing Laws to Fight Bioterrorism, THE WASH. POST, November 19, 2001, at A01. Only a few days later the state passed a budget that slashed public health programs and the Governor vetoed part of that program, imposing further cuts on public health. See Rick Klein, Legislators are Likely to Restore Social Funding, BostON GLOBE, Dec. 5, 2001, at B-4.

${ }_{124}$ Steven Erlanger, Bush's Move on ABM Pact Gives Pause to Europeans, N.Y. TIMES, Dec. 13, 2001, at A-19.

${ }^{125}$ Peter Slevin, U.S. Drops Bid to Strengthen Germ Warfare Accord, WASH. PosT, Sept. 19, 2002, at A01. 
dangerous pathogens. ${ }^{126}$ Nevertheless, if we focus upon law's ability to regulate and structure markets, as opposed to its ability to restrain individuals, gaps appear. For example, although the PHSBPRA gives the Secretary of Agriculture authority to expand the capacity of the Food Inspection Service to protect against bioterrorism, the Act does not provide anything close to a comprehensive approach for inspection and protection of the food supply. In a recent report, ${ }^{127}$ the National Academy of Science warned that inadequate attention has been given to this issue and the nation remains vulnerable to a bioterrorist attack on the food supply. ${ }^{128}$ Likewise, the PHSBPRA does not require states to rebuild their broken public health systems to ensure the "dual-use' capacity that is so clearly needed. ${ }^{129}$ While the PHSBPRA authorizes grants to help states address bioterrorism, ${ }^{130}$ the danger remains that states will remain unprepared as their public health systems as a whole remain unsupported. ${ }^{131}$

At the state level, once we move away from thinking about law as coercion, other significant issues appear. Once again, the most obvious issue concerns resources. Laws allocate resources - and they can also create entitlements to them. Yet, we have not considered in our legal preparation for bioterrorism the creation of any entitlement to the resources necessary to confront bioterrorism. Indeed, while the Model Act would grant governors the authority to exercise emergency powers, there is nothing in the Act to commit states to undertake the deployment of resources that is crucial to preparing for bioterrorism.

Theoretically, a state law aiming at bioterrorism could focus not on the state's power to mandate vaccines, but on ensuring that vaccines will be available and administered smoothly, when needed. Indeed, guidelines recently released by the CDC for states to use in preparing a response to a potential outbreak of smallpox raise a host

${ }^{126}$ Pub. L. No. 107-188, $\S \S 131$ et seq; 201 et seq; 301, 116 Stat. 594 (2002) (codified at 42 U.S.C. $\S \S 243 ; 262$ et seq.)

12721 U.S.C. $\$ 679$ (c) $(2000)$.

${ }^{128}$ National Academies, Better Plan Needed to Protect U.S. Agriculture from Bioterror Attack, at http://www4.nationalacademies.org (Sept. 19, 2002).

${ }^{129}$ Experts agree that preparation for bioterrorism requires an overall enhancement of the public health infrastructure, which should be built upon and would expand public health's capacity to respond to naturally occurring disease outbreaks. See General ACCOUNTING OFFICE, BIOTERRORISM-FEDERAL RESEARCH AND PreparedNESS ACTIVITIES, GAO-01-915 (September 2001), at 6. A pressing problem today is that investments made for bioterrorism preparedness activities will not offset cuts made elsewhere in public health budgets, thereby weakening the overall public health infrastructure. See note 124, supra.

${ }^{130} 42$ U.S.C. § 247d-3(a).

${ }_{131}$ See Gostin et al., supra note 71, at 95-97 (discussing the decline in funding and support for state public health systems). 
of important legal questions for Congress and the states to address, many of which are unanswered by the Model Act. ${ }^{132}$ Although the original CDC guidelines cited to and recommended the Model Act, ${ }^{133}$ and the recent additions continue to rely in part upon quarantine, ${ }^{134}$ their primary focus is upon the implementation of a massive, population-wide campaign of voluntary vaccination. ${ }^{135}$ If such an effort is to be carried out successfully, it will undoubtedly require a great deal of trust and confidence on the part of the public and this may well require new and creative legal approaches. For example, the CDC's mass vaccination program depends upon individuals revealing whether they are immune suppressed, something that experience with HIV suggests individuals may be far more likely to do if they feel comfortable knowing that the information will be kept confidential and not be used against them. ${ }^{136}$ As a result, states interested in facilitating a massive vaccination program may want to consider taking additional steps to ensure that information conveyed in a vaccination clinic would not be further disseminated and could not be used against an individual (indeed, the possibility that this information might be used to mandate isolation apart from one's family may lead people to not be forthright at the clinics). Likewise, since a mass effort will inevitably lead to long lines and confusion, states may want to consider ensuring that individuals are protected against adverse employment (or welfare) impacts for the time lost at the clinic. States may also want to give thought on ways to guarantee that individuals who lack health insurance can be confident in receiving prompt care for vaccine-related injuries. And states may want to reassure health care workers that they will not be liable for the injuries that will inevitably result from a massive vaccination program. ${ }^{137}$ Given the complexities

${ }^{132}$ Centers for Disease Control and Prevention, Smallpox Response Plan and Guidelines, Guide C: Isolation and Quarantine Guidelines C-14 to C-17, at http://www.bt.cdc.gov/agent/smallpox/response-plan/files/guide-c-pages1-18only.pdf (last modified Sept. 23, 2002).

${ }^{133}$ Id. at C-14 to C-15.

134 See Centers for Disease Control and Prevention, Smallpox Response Plan and Guidelines; Annex 3: Smallpox Vaccination Clinic Guide, A3-31, 37, at $\mathrm{http}: / / \mathrm{www} . b t . c d c . g o v / a g e n t /$ smallpox/response-plan/files/annex-3.pdf (last modified Sept. 23, 2002) (providing guidelines for isolating patients).

${ }_{135} \mathrm{Id}$. at A3-3, at http://www.bt.cdc.gov/agent/smallpox/responseplan/files/annex-3.pdf (last modified Sept. 23, 2002).

${ }^{136}$ The guidelines call for different treatment for individuals depending upon their immune status. Id. at A3-29.

${ }_{137}$ See Katharine C. Rathbun \& Edward P. Richards, Federal Smallpox Immunization Policy-A Short Critique, available at http://biotech.law.lsu.edu/blaw/bt/smallpox/Critique01.htm (Sept. 26, 2002) (noting that, "[g]iven the probable level of vaccine complications, litigation would cripple the 
and challenges of such a massive program, there is more than enough legal work to be done without thinking about the powers to coerce individuals. Indeed, in such circumstances, a focus upon coercion may well serve to undermine the trust of the public.

Likewise, in developing quarantine strategies, a state may want to go beyond enhancing its powers to impose detention orders and providing legal process for those who are detained involuntarily. Instead, a state may want to give thought to how voluntary quarantine and/or isolation recommendations may be more tolerable and acceptable to the population. In other words, the state may want to think about how it can promote voluntary compliance. After all, the state will never have sufficient resources to "round up" and involuntarily detail large numbers of people. But in order to obtain voluntary compliance, states may need to move beyond a police power model, and think not only about how they can enforce laws and protect legal rights of those detained, but also how they can make quarantine less frightening and more palatable. The Model Act moves in that direction by requiring that states provide for the needs of those involuntarily detained, but as noted above, it does not specifically address the economic consequences of quarantine, nor does it ensure that dependents will be care for. ${ }^{138}$ In addition, the Model Act does not provide for the care or compensation of individuals who stay put without the imposition of a public health order. But, if quarantine is critical to the public good, then perhaps like jury duty or reserve duty, those who serve (voluntarily or involuntarily) should be provided with job protection and compensation.

In preparing for bioterrorism, a state may also want to consider ways that law can be used to ensure that health care facilities will have the needed surge capacity. While the Model Act gives the states power to impound facilities during an emergency, ${ }^{139}$ it does not consider the complex and difficult issue of how state health care licensing and financing regulations affect the number of beds and personnel on hand in the state. Yet, if law is to be used to prepare for and against bioterrorism, these issues must be part of the preparation.

Finally, once we turn our eyes to structural approaches we may discover that they also offer some promise not only for protection against bioterrorism but for the protection of individual rights and liberties in the event an emergency occurs. The Model Act relies heavily upon the courts and the protections offered by individual hear-

public health system").

${ }_{138}^{138}$ MODEL ACT, supra note 3, at $\S 604(\mathrm{~b})(6)$.

139 Id at $\S 502(\mathrm{~b})$. 
ings. But in times of crisis, this approach has seldom proven successful.

The political theory of our founding fathers offered a different, structural approach. The Constitution relies primarily not upon judicial review or due process hearings, but the division of power and checks and balances in order to thwart tyranny. As James Madison famously said, "ambition must be made to counteract ambition." 140

So, too, as we prepare for bioterrorism, we need to think long and hard about the structures of government, and how they can be most effectively utilized both to invigorate the public sector to prevent and respond to bioterrorism and to prevent the misuse of such powers. That may mean rethinking the boundaries of federalism and developing legal theories to provide the federal government with the power it may need to address problems national in scope as well as limits upon it to prevent an erosion of legitimate state interests. ${ }^{141}$ At the state level, it may mean thinking carefully about the relationship between governors, state health departments, local health departments, and legislators. To give one example, while it seems obvious that governors may need the power to act quickly in the event of a catastrophe, the Model Act's decision to prevent state legislatures from repealing any declaration of an emergency for thirty days may unnecessarily remove a structural and political check upon the misuse of authority, a check that might well do more to curtail unnecessary limitations upon individual rights than would due process hearings. Likewise, the Act's reliance on the governor alone, without the necessity of consultation by the public health department, or municipal leaders, again appears to vest authority in a single source, negating the possibility that multiple centers of power (what we use to call "checks and balances"), may offer the best opportunity to define and preserve the common good, without unduly disadvantaging minority groups.

When health threats appear, as in times of war, there is an inevitable tendency to focus on the need for efficient power and the virtues of a powerful executive. But just as our framers taught us that the preservation of peace requires a far more complex and less tidy political state than is needed to win a war, so too, we may recall that the protection of public health whether from bioterrorism or natural causes ultimately requires complex and multifaceted laws. There is a lot of work for lawyers yet to do.

140 The Federalist Papers No. 51, at 319 (James Madison) (Isaac Kramnick ed., 1987).

${ }^{141}$ See Annas, supra note 25 at 1337, 1341; Parmet, supra note 83, at 207-08. 
